s-

$\hat{s}$

o.

$10-$

:!

$: 2$

$: 3$

$\because$

$\because$

$: \hat{}$

$: 0$

$\therefore-$

21

22

$=2$

22
DEPARTMENT OF THE INTERIOR

U.S. GEOLOGICAL SURVEY
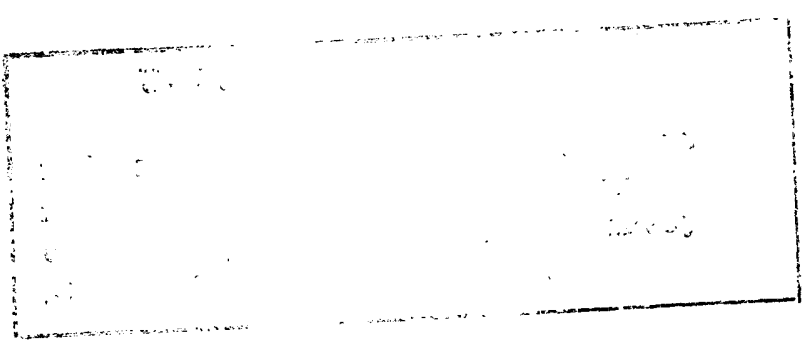

Cobalt in the United States

(Material compiled up to 1963)

by

J.S. Vhay

1979

Open-File 79-1436 
COBALT IN THE UNITED STATES

(Material compiled up to 1963)

by J. S. Vhay

Deposits of cobalt in the United States are shown on the accompanying map. Size category, geologic type, and approximate metal content are shown by the map symbols. Occurrences within each State are numbered on the map and Identified by number in the index, where they are also listed by geographic coordinates and, where applicable, by county and section, township, and range. Both published sources and data in the files of the Geological Survey were used in compiling the map; the more important published reports are cited.

Cobalt is closely related, chemically, to iron, occurring in the same "box" with iron in the periodic table. Its average abundance in the igneous rocks of the earth's crust is $20 \mathrm{ppm}$ (Unksov and Lodochuikova, 1961). However, cobalt is more abundant in more mafic rocks and is relatively depleted in more felsic rocks. The average amounts of cobalt in parts per million (ppm) in igneous rocks (in order, approximately, of increasing silica) are:

All mafic rocks $\frac{\text { Co }}{51}$

Basalt 41

Gabbro

Diabase and dolerite 31

Intermediate rocks 14

Felsic rocks 5 
Most rocks are weathered before being eroded. Except for lateritic soils that develop on ultramafic rocks, the amount of cobalt in soils is surprisingly constant, with a range of between 1.5 and $18 \mathrm{ppm}$, and an average of $9 \mathrm{ppm}$. Lateritic soils are usually much richer in cobalt (up to $0.1 \%$ ) which occurs mostly as a residual surface enrichment in manganese oxides (Pecora, 1944).

After erosion, most cobalt reaches areas of sedimentation in solution. It is deposited mainly with clay materials, or iron or manganese oxides, and is also concentrated to some extent in carbonaceous material. The amounts of cobalt in sandstone and limestone are very low, depending mostly on the amounts of clay, iron, and manganese present as impurities. In normal shales, the cobalt content usually is about $8 \mathrm{ppm}$, while black shales have between $5-50 \mathrm{ppm}$ cobalt and carbonaceous shales about $14 \mathrm{ppm}$ cobalt. The amounts of cobalt in certain special types of sediments may be considerably greater than average values; e.g., for iron-rich sediments (20-300 ppm Co), for ashed coals as much as 1,500 ppm Co, and ashed petroleum may average $920 \mathrm{ppm}$ Co but contain as much as 9,000 ppm Co.

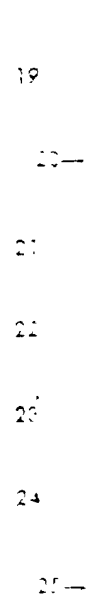

$\therefore-$ 
Manganese, under oxidizing conditions, has a strong affinity for a number of metals, including cobalt. Under very slow conditions of deposition, as occur on the bottoms of the oceans, manganese precipitates as a colloid which picks up cobalt ions present in

s- solution. The manganese then coalesces and forms manganese nodules.

4 Where deposition of other materials, siliceous, argillaceous, or

7 carbonate, is too rapid to allow the formation of nodules, then the manganese oxides, together with other materials, will occur disseminated in the sediments in amounts that are inversely proportional to the :0- rate of sedimentation. When these deposits are later exposed and weathered, the manganese is very insoluble, and, together with the contained cobalt, forms concentrations near the surface (e.g., in the Appalachians and Missouri); in places, these concentrations are of economic importance.

is- Little change in the amounts of cobalt present occurs during metamorphism. Those rocks high in cobalt (ultramafic and mafic igneous rocks) become serpentine, steatite, or chlorite schist and have the same relative amounts of cobalt as are found in the original 10 rocks. Most other metamorphic rocks are 1ow in these elements. $20-$ 


\section{Deposits of cobalt}

Cobalt is recovered from a number of different deposit types. The following are the most important.

Ultramafic and mafic rocks in many places contain deposits of pentlandite, chalcopyrite, and pyrrhotite. These deposits are often important sources of nickel and copper; the cobalt content of these deposits is usually between one-twentieth and one-thirtieth of the amount of nickel-plus-copper in the deposit. The Gap mine (Pennsylvania) and the San Julian mine (California), are examples of this type of deposit.

Contact deposits, formed by diabase intruding limestone, in places have important magnetite orebodies. These contain minor amounts of cobaltiferous pyrite. The Cornwall and Grace mines in Pennsylvania are of this type.

Hydrothermal vein deposits may also contain significant amounts of cobalt. The metal content of these deposits varies widely. Some, like the Bluebird mine (Arizona), are small deposits containing mostly only cobalt minerals. At the Standard mine (Oregon), the cobalt minerals are associated with considerable gold, and copper is present in separate ore shoots. In the Blackbird district (Idaho), the amount of copper present is greater than the amount of cobalt (Cu, 1.6 percent; Co, 0.6 percent), and minor amounts of gold, bismuth, and nickel are present. The Blackhawk district (New Mexico), is a silvercobalt-nickel type hydrothermal vein deposit which also has some uranium.

2.4 
A second type of hydrothermal deposit is the "stratabound" Mississippi Valley type deposits. These contain mostly sulfides of lead, zinc, iron, and copper, but some contain significant cobalt.

The massive sulfide deposits, such as are found in the Appalachians, are valuable mainly for the pyrite or pyrrhotite they contain, as they are mined primarily for the sulfur and iron; some by-product copper and zinc may also be produced. However, in some deposits, cobalt is present in pyrite (Ducktown, Tennessee).

Weathering is responsible for two types of deposits from which nickel and cobalt are or may be recovered. The laterites developed on ultramafic rocks under tropical conditions contain some cobalt which is usually concentrated in the upper part of the soil profile in association with manganese oxides. Lateritic deposits at Riddle, Oregon, and at Cle Elum, Washington, are examples. Cobalt also is concentrated in manganese deposits that are exposed and concentrated by weathering.

Stratabound copper deposits in shales and dolomites also contain cobalt-bearing sulfide deposits. Deposits of this type in Zaire and Zambia are the world's major sources' of cobalt. Similar deposits are not known in the United States. 


\section{Brief history of production in the United States}

A deposit near Chatham, Connecticut, produced minor amounts of cobalt intermittently between the years 1763 and 1853. The Gap mine, Pennsylvania, supplied nickel and cobalt to United States markets from 1860 to 1893; the deposit is described as segregated sulfides in a mafic intrusion similar to those in the Sudbury Basin. From 1893 until about 1900 small amounts of cobalt were produced both at Mine La Motte, Missouri, and from mines near Lovelock, Nevada. In the early 1900 's a few shipments of cobalt-rich ore, carrying considerable gold also, were sent to France from the Quartzburg district, Oregon. During the periods $1906-1910$ and $1917-1920$ attempts were made to recover cobalt from the lead ore at Fredericktown, Missouri. Also in the period 1917-1920, some cobalt was produced at the Haynes Stellite mine in the Blackbird district, Idaho. In 1921 and 1922, numerous small high-grade shipments of cobalt oxide ore (heterogenite) were made from the Goodsprings district, Nevada; the total contained cobalt, however, was only about 4,650 pounds. The electrolytic zinc plant at Kellogg, Idaho, recovered some cobalt from its sludge but so far as- - known, this cobalt has never reached the open market. The magnetite mine, Cornwall, Pennsylvania, began producing by-product cobalt in 1940 (cobalt production ceased in 1971). The Fredericktown, Missouri, lead mine shipped nickel-cobalt concentrates for refining during the period 1941 to 1945; this ore deposit was also in production from 1955 to 1960. The Calera mine, Idaho, produced cobalt from 1952 to 1959 


\section{References cited}

Anderson, C.A., Scholz, E.A., and Strobe11, J.D., Jr., 1956, Geology and ore deposits of the Bagdad area, Yavapai County, Arizona: U.S. Geol. Survey Prof. Paper 278, 103 p.

Bancroft, H., 1914, The ore deposits of northeastern Washington: U.S. Geo1. Survey Bu11. 550, 215 p.

Binyon, E.0., 1948, Gibellini manganese-zinc-nickel deposits, Eureka County, Nevada: U.S. Bur. Mines Rept. Inv. 4162, 9 p.

Bogert, J.R., 1960, How ferronickel is produced from low grade laterite by the Ugine Process: Mining World, v. 22, no. 11, p. 33-37.

Burchard, E.F., and others, 1934, The brown iron ores of the western Highland, Tennessee: Tennessee State Dept. Education, Div. Geology Bul1. 39, p. 116.

Burchard, E.F., and Andrews, T.G., 1947, Iron ore outcrops of the Red Mountain formation in northeastern Alabama: Alabama Geol. Survey Spec. Rept. 19.

Cole, J.W., 1944,Mackinaw Metals mine: U.S. Bur. Mines War Minerals Rept. 156.

Cornwal1, H.R., 1966, Nickel deposits of North America: U.S. Geol. Survey Bul1. 1223, 62 p.

Cornwall, H.R., and Burbank, W.S., 1952, Nickel reserves of the world, C hap. $\mathrm{V}$ in Materials Survey: Nickel: U.S. Bureau Mines, p. V-I-V-39.

Cox, M.W., and Wyant, D.G., 1948, The Jesse Belle Copper Mine, Madera County, California, in Jenkins, 0.P., Copper in California: California Div. Mines Bul1. 144, p. 151-157. 
Creasey, S.C., 1946, Geology and nickel mineralization of the JulianCuyamaca area, San Diego County, California: California Jour. Mines and Geology, Rept. 42, p. 15-30.

Crittenden, M.D., and Pavlides, L., 1962, Manganese in the United

-- States: U.S. Geol. Survey Mineral Inv. Resource Map MR-23.

Dole, H.M. and others, 1948, Nickel-bearing laterite areas of southwestern Oregon: The Ore.-BIn, v. 10, no. 5, p. 33-38.

Egleston, T., 1881, Investigations on the Ore Knob copper process: Am. Inst. Mining Metal1. Engineers Trans., v. 10, p. 28.

- Emmons, S.F., and others, 1894, Description of the Anthracite-Crested Butte quadrangle (Colorado): U.S. Geol. Survey Geol. Atlas, Folio 9. Eric, John H., 1948, Tabulation of copper deposits of California, in Jenkins, O.P., Copper in California: California Div. Mines Bull. 144, p. 259, 321, 333 .

Ferguson, H.G., 1939, Nickel deposits in Cottonwood Canyon, Churchill County, Nevada: Univ. Nevada Bull., v. 33, no. 5, 21 p.

Fryklund, V.C., Jr., and Hutchinson, M.W., 1954, The occurrence of cobalt and nickel in the Silver Summit mine, Coeur d'Alene district, Idaho: Econ. Geology, v. 49, no. 7, p. 753-758.

Gillerman, E., and Whitebread, D.H., 1956, Uranium-bearing nicke1-cobaltnative silver deposits, Black Hawk district, Grant County, New Mexico: U.S. Geol. Survey Bull. 1009-K, p. 283-313.

Goddard, E.N., and Lovering, T.S., 1942, Nickel deposits near Gold Hill, Boulder County, Colorado: U.S. Geol. Survey Bul1. 931-0, p. 349-362. 
Grosh, W.A., and others, 1955, Investigation of copper-nickel mineralization in Kawishiwi River area, Lake County, Minnesota: U.S. Bur. Mines Rept. Inv. 5177, 18 p.

Harder, E.C., 1910, Manganese deposits of the United States: U.S. Geol. Survey Bul1. 427, p. 75 .

Hess, F.L., 1927, Cobalt: U.S. Bur. Mines Mineral Resources, U.S., 1924, pt. 1, p. 451 .

Hewett, D.F., 1931, Geology and ore deposits of the Goodsprings quadrangle, Nevada: U.S. Geol. Survey Prof. Paper 162, 172 p. Hewett, D.F., and Fleischer, M., 1960, Deposits of the Manganese oxides: Econ. Geology, v. 55, no. 1, p. 1-55.

Heyl, A.V., and Pearre, N.C., 1965, Copper, zinc, lead, iron, cobalt, and barite deposits in the Piedmont Upland of Maryland: Maryland Geol. Survey Bu11. 28, $71 \mathrm{p}$.

_ Hobbs, S.W., and Pecora, W.T., 1941, Nickel-gold deposit near Mount Vernon, Skagit County, Washington: U.S. Geo1. Survey Bu11. 931-D, p. $57-78$.

Hotz, P.E., 1964, Nickeliferous laterites in southwestern Oregon and northwestern California: Econ. Geology, v. 59, no. 3, p. 355-396. Hundhausen, R.J., 1952, Investigation of Shamrock copper-nickel mine, Jackson County, Oregon: U.S. Bur. Mines Rept. Inv. 4895, 12 p. Hundhausen, R.J., and others, 1954, Preliminary investigations of the Red Flats nickel deposit, Curry County, Oregon: U.S. Bur. Mines Rept. Inv. 5072, 19 p. 
Huntting, M.T., 1943, Inventory of mineral properties in Chelan County, Washington: Washington Div. Geology Rept. Inv. 9.

Julihn, C.E., and Horton, F.W., 1940, Mineral Industries Survey of the United States: California, II Toulmne and Mariposa Counties: U.S. Bur. Mines Bul1.424.

Kennedy, G.C., and Walton, M.S., Jr., 1946, Geology and associated mineral deposits of some ultrabasic rock bodies in southeastern Alaska: U.S. Geo1. Survey Bul1. 947-D, p. 65-84.

King, P.B., 1950, Geology of the Elkton area, Virginia: U.S. Geol. Survey Prof. Paper 230, p. 66-67.

King, P.B., and others, 1944, Geology and manganese deposits of northeastern Tennessee: Tennessee Dept. Conserv., Div. Geology Bull. 52 . Kingston, Jack, and Miller, D.J., 1945, Nickel-copper prospect near Spirit Mountain, Copper River region, Alaska: U.S. Geol. Survey Bull. 943-C, p. 49-57.

Kinke1, A.R., Jr., and Peterson, N.P., 1962, Copper in the United States, exclusive of Alaska and Hawail: U.S. Geol. Survey Map MR-13.

Knechtel, M.M., 1943, Manganese deposits of the Lyndhurst-Vesuvius district, Augusta and Rockbridge Counties, Virginia: U.S. Geol. Survey Bu11. 940-F, p. 163-198.

Knopf, E.B., and Jonas, A.I., 1929, Geology of the McCalls Ferry-Quarryville district, Pennsylvania: U.S. Geol. Survey Bull. 799, 156 p.

Ladd, H.S., 1944, Manganese deposits of the Sweet Springs district, West Virginia and Virginia: U.S. Geol. Survey Bull. 940-G, p. 199-217. 
Ladd, H.S., and Stead, F.W., 1944, Manganese deposits of the Flat Top and Round Mountain districts, Bland and Giles Counties, Virginia:

U.S. Geol. Survey Bul1. 940-H, p. 219-245.

Lindgren, W., 1900, Description of the Colfax quadrangle (California):

U.S. Geo1. Survey Geol. Atlas, Follo 66.

Lovering, T.S., and Goddard, E.N., 1950, Geology and ore deposits of the

Front Range, Colo.: U.S. Geol. Survey Prof. Paper 223, 319 p.

Mertie, J.B., Jr., 1937, The Yukon-Tanana region, Alaska: U.S. GeoI. Survey Bull. 872, 276 p.

Miller, R.L., 1944, Geology and manganese deposits of the Glade Mountain district, Virginia: Virginia Geol. Survey Bull. 61.

Mi11s, J.W., 1960, Geologic setting of the nickel occurrences on Jumbo Mountain, Washington: Mining Eng., v. 12, no. 3 (March), p. 272-274. Milton, C. and Milton, D.J., 1958, Nickel-gold ore of the Mackinaw mine, Snoomish County, Washington: Econ. Geology, v. 53, no. 4, p. 426-447.

Monroe, W.H., 1942, Manganese deposits of Cedar Creek Valley, Frederick and Shenandoah Counties, Virginia: U.S. Geol. Survey Bul1. 936-E. Murdock, J. and Webb, R.W., 1956, Minerals of California: California Div. Mines Bull. 173, p. 260.

Needham, A.B., and others, 1950, Investigation of the Great Eastern Nickel Deposit, Clark Co., Nevada: U.S. Bur. Mines Rept. Inv. 4679, 5 p. Ohle, E.L., and Brown, J.S., 1954, Geologic problems in the Southeast Missouri lead district: Geol. Soc. America Bull., v. 65, no. 3, p. 202-221. 
Palache, C., and others, 1944, Dana's system of Mineralogy, 7th ed.: New York, John Wiley and Sons, Inc., p. 345.

Pardee, J.T., and Park, C.F., Jr., 1948, Gold deposits of the southern

Piedmont: U.S. Geol. Survey Prof. Paper 213, 156 p.

Patty, E.N., 1921, The Metal Mines of Washington: Washington Geol. Survey Bull. 23.

Patty, E.N., and Kelly, S.F., 1945, A geological and geophysical study of the Chelan nickel deposit near Winesap, Washington: Am. Inst. Mining Metall. Engineers Tech. Pub1. 1953.

Pecora, W.T., and Hobbs, S.W., 1941, Nickel deposit near Riddle, Douglas County, Oregon: U.S. Geol. Survey Bul1. 931-I, p. 205-226. Phemister, T.C., 1924, A note on the Lancaster Gap mine, Pennsylvania: Jour. Geology, v. 32, no. 6, p. 498-510.

Pierce, W.G., 1944, Cobalt-bearing manganese deposits of Alabama, Georgia, and Tennessee: U.S. Geol. Survey Bull. 940-J, p. 265-285. Reed, J.C., 1942, Nickel-copper deposit at Funter Bay, Admiralty Island, Alaska: U.S. Geo1. Survey Bu11. 936-0, p. 51-52.

Reed, J.C., and Gates, G.0., 1942, Nickel-copper deposit at Snipe Bay, Baranof Island, Alaska: U.S. Geol. Survey Bull. 936-M, p. 321-348. Ross, C.S., 1935, Origin of the copper deposits of the Ducktown type in the southern Appalachian region: U.S. Geol. Survey Prof. Paper $179,165 \mathrm{p}$.

Schwartz, G.M., and Davidson, D.M., 1952, Geologic setting of the coppernickel prospect in the Duluth gabbro near Ely, Minnesota: Mining Engineering, v. 4, no. 7, p. 699-702. 
Shelton, J.E., 1956, Beneficiation studies of nickeliferous ores from the Shamrock mine, Jackson County, Oregon and the Congress mine, Ferry County, Washington: U.S. Bur. Mines Rept. Inv. 5261.

Shenon, P.J., 1933, Geology and ore deposits of the Takilma-Waldo district, Oregon, including the Blue Creek district: U.S. Geol. Survey Bull. 846-B, p. 141-194.

Short, M.N., 1940, Microscopic determination of the ore minerals: U.S. Geol. Survey Bul1. 914, 314 p.

Sims, S.J., 1968, The Grace mine magnetite deposit, Berks County, Pennsylvania, in Ore Deposits in the United States, 1933-1967, Rocky Mountain Series, A.I.M.E., v. I, p.

Snyder, F.G., and Odeli, J.W., 1958, Sedimentary breccias in the southeast Missouri lead district: Geol. Soc. America Bull., v. 69, no.7, p. 899-926.

Stead, F.W., and Stose, G.W., 1943, Manganese and quartzite deposits in the Lick Mountain district, Wythe County, Virginia: Virginia Geol. Survey Bul1. 59.

Sterling, P.J., and Stone, C.G., 1961, Nickel occurrences in soapstone deposits, Saline County, Arkansas: Econ. Geology, v. 56, no. 1, p. $100-110$.

Stose, G.W., and others, 1919, Manganese deposits of the west foot of the Blue Ridge, Virginia: Virginia Geol. Survey Bul1. 17, p. 83-96. Stose, G.W., and Miser, H.D., 1922, Manganese deposits of western Virginia: Virginia Geol. Survey Bul1. 23, p. 134-142. 
Stose, G.W., and Schrader, F.C., 1923, Manganese deposits of east Tennessee: U.S. Geol. Survey Bul1. 737, $154 \mathrm{p}$.

Tarr, W.A., 1936, Origin of the southeastern Missouri lead deposits:

Econ. Geology, v. 31, nos. 7 and 8, p. 712-754, 832-866.

Unksov, V.A., and Lodochnikova, N.Y., 1961, Abundance of cobalt and nickel

in igneous rocks and the earth's crust: Geochemistry, No. 9, p. 801812.

Vhay, J.S., 1952, Cobalt Resources, Chap. VI in Materials Survey:

Cobalt: National Security Resources Board.

1959, The copper-cobalt deposits of the Quartzburg district, Grant

County, Oregon: U.S. Geol. Survey open-file report.

1964, Cobalt and nickel, in Mineral and Water Resources of Idaho:

U.S. Cong. 88th, 2nd Sess., pp. 66-68.

1966, Nickel and cobalt in Mineral and water resources of Washington:

Washington Dept. Conserv., Div. Mines and Geology Reprint 9,

p. $116-125$.

Wagner, W.R., 1949, The geology of part of the south slope of the St. Joe

Mountains, Shoshone County, Idaho: Idaho Bur. Mines and Geology

Pamph. 82, 47 p.

$\therefore$-Watson, T.L., 1908, The occurrence of nickel in Virginia: Am. Inst.

Mining Metall. Engineers, Trans., v. 38, p. 683-697.

Weed, W.H., 1911, Copper deposits of the Appalachian States: U.S. Geol.

Survey Bul1. 455, p. 157-160.

Young, R.S., 1968, Mineral exploration and development in Maine: in

Ore deposits of the United States 1933-1967, Rocky Mountain Series,

A.I.M.E., v. I, p. 125-139, Graton-Sales Vol. 
INDEX

Locality

Lat. $\mathrm{N}$.

Long $W$.

ALABAMA

1. Walnut Grove district. Blount Co. T. 11 S., R. 3 E. $34^{\circ} 04^{\prime}$

$86^{\circ} 20^{\prime}$

Manganese oxides in Fort Payne chert and overlying soil. Crittenden and Pavlides, 1962; Burchard and Andrews, 1947.

2. Greasy Cove. Etowah Co. Sec. 11, T. 12 S., R. 4 E.

Manganese oxides in weathered Fort Payne chert.

Plerce, 1944.

3. Harbour and Thompson prospects. Cherokee Co. Secs.

18,20, T. $12 \mathrm{~S} .$, R. $10 \mathrm{E}$. Manganese oxides in

soil overlying. Floyd shale(?). Pierce, 1944.

4. Rock Run area. Cherokee and Cleburne Cos. T. 12 S.,

$34^{\circ}$

$85^{\circ} 25^{\prime}$

R. $11 \mathrm{E}$. Manganese oxides in weathered Weisner

quartzite and Knox dolomite. Pierce, 1944.

5. Burke Estate. Calhoun Co. T. 14 S., R. 9 E.

$33^{\circ} 48^{\prime}$

$85^{\circ} 4^{\prime}$

Manganese oxides. Pierce, 1944.

6. Dulin. Clay Co. Sec. 14, T. 18 S., R. 8 E.

$33^{\circ} 27^{\prime}$

$85^{\circ} 46^{\prime}$

Manganese oxides deposited in fractures in

weathered Talledega slate. Plerce, 1944.

7. Stone Hill. Cleburne Co. T. 17 S., T. 17 and

$33^{\circ} 29^{\prime}$

$85^{\circ} 27^{\prime}$

8 S., R. 11 E. Cupriferous iron sulfides

replacing Hillabee chlorite schist. (Ross,

1935; Weed, 1911).

8. Unnamed Prospect. Gosher Valley Area. Cherokee

$33^{\circ} 58^{\prime}$

$85^{\circ} 37^{\prime}$

Co. Pellet-type ore. $0.14 \%$ Co. T. $12 \mathrm{~S}$. ,

R. 10 E., Sec. 20. Pierce, 1944.

\section{ALASKA}

1. Barrett property, Hot Springs Dome, Lower Tanana

$65^{\circ} 02^{\prime}$

$150^{\circ} 45^{\prime}$

River. Vein in granite carries mixed sulfides.

Mertie, 1934.

2. Eagle district prospect. Yukon River. Cobaltnickel sulfide vein in greenstone. Mertie, 1937.

$64^{\circ} 48^{\prime}$

$141^{\circ} 12^{\prime}$ 


$$
\text { ALASKA--Continued }
$$

3. Spirit Mountain. Copper River area, Canyon Creek. Copper-nickel sulfides in peridotites sill. Kingston and Miller, 1945.

4. Mt. Crillon. East of Lituya Bay. Banded basic intrusion. Kennedy and Walton, 1946.

5. Admiralty-Alaska Gold. Funter Bay. Admiralty Island. Plunging gabbro pipe with disseminated copper-nickel sulfides. Reed, 1942.

6. Bohemia Basin. Yakobi Island. Norite body carrying disseminated copper-nickel sulfides. Kennedy and Walton, 1946.

7. North tip Fleming Island, 3 prospects. Chichag of Island. Disseminated copper-nickel sulfides in norite bodies. Pecora, 1942; Kennedy and Walton, 1946.

8. Snipe Bay prospect. Baranof Island. Albitized norite with copper-nickel sulfides. Reed and Gates, 1942.

\section{ARIZONA}

1. Old Dick. Yavapai Co. Sec. 17, T. 14 N., R. 9 W. Anderson, Scholz, and Strobell, 1956.

2. Walker prospect. Yavapai Co. Sec. 8, T. 14 N., R. 2 E. Cobaltian arsenopyrite in small vein. Vhay, 1952 .

3. Bluebird, Graham Co. Sec. 5, T. 5 S., R. 21 E. Cobaltite, glaucodot, and chalcopyrite in vein in quartzite.

\section{ARKANSAS}

1. Sugarstick. Polk and Pike Cos. Manganese oxide vein- $34^{\circ} 23^{\prime}$ $93^{\circ} 50^{\prime}$ lets in novaculite. Hewett and Fleischer, 1960; Crittenden and Pavlides, 1962.

2. Saline Co. Nickel in soapstone and lateritic serpentine. $34^{\circ} 4^{\prime}$ ' 


\section{CALIFORNIA}

1. Kane and Wilbur. Shasta Co. Sec. 24, T. 34 N., R. 4 W.

$40^{\circ} 4^{\prime}$

$122^{\circ} 16^{\prime}$

Magnetite in skarn deposit; copper and nickel reported.

Eric, 1948.

2. Prospect. Nevada Co. Sec. 20, T. 17 N., R. 13 E.

Chalcopyrite and cobaltite disseminated in schist.

$39^{\circ} 20^{\prime}$

$120^{\circ} 33^{\prime}$

Lindgren, 1900.

3. Digitalli. Jackson district. Amador Co. Sec. 36,

T. $6 \mathrm{~N} .$, R. $11 \mathrm{E}$. Cobaltiferous manganese oxide in

oxidized zone of gold-quartz vein. Vhay, 1952.

4. Mokelumne Hill, prospect. Calaveras Co. T. 5 N.,

R. 12 E. "Asbolite." Murdock and Webb, 1956.

$38^{\circ} 18^{\prime}$

$120^{\circ} 41^{\prime}$

5. Marjon. Sheepranch district. Calaveras Co. T. 4 N.,

$38^{\circ} 11^{\prime}$

$120^{\circ} 27^{\prime}$

R. 14 E. Glaucodot in fault in schist. Hess, 1927.

6. Jenny Lind prospect. Calaveras Co. T. 3 N., R. 11 E.

$37^{\circ} 31^{\prime}$

$120^{\circ} 46^{\prime}$

"Asbolite" reported. Murdock and Webb, 1956.

7. Pine Tree and Josephine. Mariposa Co. Sec. 8,

$37^{\circ} 36^{\prime}$

$120^{\circ} 07^{\prime}$

T. 4 S., R. 17 E. Gold-quartz vein on Mother Lode;

Numerous sulfides. Nickel and cobalt present.

Eric, 1948; Julihn and Horton, 1940.

8. Green Mountain. Mariposa Co. Sec. 3, T. 8 S.,

$37^{\circ} 17^{\prime}$

$120^{\circ} 00^{\prime}$

R. $18 \mathrm{E}$. Pyrrhotite-chalcopyrite ore bodies in

schist. Eric, 1948.

9. Buchanan. Madera Co. Sec. 34, T. 8 S., R. 18 E.

Pyrrhotite-chalcopyrite ore in schist. Eric, 1948.

$37^{\circ} 11^{\prime}$

$120^{\circ} 00^{\prime}$

10. Jesse Belle. Madera Co. T. 9 S., R. 18, 19 E.

$37^{\circ} 09^{\prime}$

$119^{\circ} 57^{\prime}$

Chalcopyrite and cobaltite in veins in schist and

gneiss. Cox and Wyant, 1948.

11. Daulton. Madera Co. Sec. 35; T. 9 S., R. 18 E.

$37^{\circ} 07^{\prime}$

$119^{\circ} 58^{\prime}$

Pyrrhotite-chalcopyrite sphalerite ore in

andalusite-schist. Eric, 1948.

12. Krohn and Ward prospect. Madera Co. Secs. 23, 26,

$37^{\circ} 02^{\prime}$

$119^{\circ} 52^{\prime}$

T. 10 S., R. 19 E. Pyrrhotite-chalcopyrite deposits;

nickel and cobalt reported. Eric, 1948.

13. Copconis prospect. Inyo Co. Sec. 23, T. 9 S.,

$37^{\circ} 09^{\prime}$

$118^{\circ} 33^{\prime}$

R. $31 \mathrm{E}$. Cobaltite and sulfides in shear zone

in roof pendant. Tucker and Sampson, 1938, Vhay, 1952. 


\section{CALIFORNIA--Continued}

Locality

14. First Chance. San Luis Obispo Co. Sec. 27, T. 28 S., R. $11 \mathrm{E}$. Copper and nickel minerals in porphyry and granite. Eric, 1948.

15. Denver group. Los Angeles Co. Secs. 10, 11, T, $3 \mathrm{~N}$. , R. $14 \mathrm{~W}$. Copper, lead, zinc, antimony, and cobalt in quartz veins in schist. Eric, 1948.

16. 01d Ironsides. San Diego Co. Segregated coppernickel sulfides in gabbro intrusion. Cornwall, 1966.

17. Friday. San Diego Co. Sec. 15, T. 13 S., R. 4 E. Copper and nickel in basic gabbro. Creasey, 1946.

COLORADO

1. Copper King (Gold Hill). Boulder Co. Sec. 14, T. 1 N. R. 72 W. Copper and nickel minerals in irregular mass replacing amphibolite schist. Goddard and Lovering, 1942; Lovering and Goddard, 1950.

2. Horace Porter. Whiterock Mountain. Gunnison Co. Sec. 33, T. 12 S., R. 85 W. Cobalt and nickel minerals with silver, in roof pendant in diorite. Emmons, 1894 ; Short, 1940.

\section{CONNECTICUT}

1. Near Chatham. Middlesex Co. Skutterudite, niccolite, and arsenopyrite in mica slate. Palache, 1944.

\section{GEORGIA}

1. Berrong. Towns Co. Copper deposit, mostly secondary. Kinkel and Peterson, 1962.

2. Gibson mine and Berkstreaser prospect. Floyd Co. Manganese oxide fills voids in weathered chert and as pellets in overlying red clay on Knox dolomite. Pierce, 1944.

3. Gemes, Ward, Bearden and Masteller. Bartow Co. Manganese oxide in residual clay overlying Shady dolomite and Rome Formation. Pierce, 1944.
Lat. N.

Long. W.

$35^{\circ} 28^{\prime}$ $120^{\circ} 46^{\prime}$

$34^{\circ} 21^{\prime}$ $118^{\circ} 20^{\prime}$

$33^{\circ} 15^{\prime}$ $116^{\circ} 45^{\prime}$

$33^{\circ} 02^{\prime}$ $116^{\circ} 34^{\prime}$

$40^{\circ} 03^{\prime}$ $105^{\circ} 28^{\prime}$ $38^{\circ} 58^{\prime}$ $106^{\circ} 53^{\prime}$

$41^{\circ} 34^{\prime}$ $72^{\circ} 33^{\prime}$ $34^{\circ} 54^{\prime}$ $83^{\circ} 44^{\prime}$ $34^{\circ} 07^{\prime}$ $85^{\circ} 15^{\prime}$ $34^{\circ} 07^{\prime}$ $84^{\circ} 40^{\prime}$ 
GEORGIA--Cont inued

4. Creighton (Franklin), Swift. Cherokee Co. Auriferous $34^{\circ} 18^{\prime}$ $84^{\circ} 17^{\prime}$ pyrite and chalcopyrite in quartz stringers in schist and gneiss. Kinkel and Peterson, 1962; Pardee and Park, 1948.

5. Penland Hill, Callahan, McCollum. Polk Co. Manganese oxide pellets in residual clay on Knox dolomite, Pierce, 1944.

6. Tallapoosa, Smith-Candless. Haralson Co. Chalcopyrite, $33^{\circ} 51^{\prime}$ $85^{\circ} 05^{\prime}$ sphalerite, and pyrite masses in schist.

7. Little Bob. Paulding Co. Massive pyrite and chalcopyrite $33^{\circ} 54^{\prime}$ In schist. Kinkel and Peterson, 1962.

8. Reeds Mountain. Carroll and Haralson Cos. Pyrite and $33039^{\prime}$ $85^{\circ} 10^{\prime}$ chalcopyrite masses in schist.

9. Jenny Stone. Carrol1 Co. Pyrrhotite and chalcopyrite $33^{\circ} 46^{\prime}$ $84^{\circ} 4^{\prime}$ in schist. Kinkel and Peterson, 1962.

10. Villa Rica. Douglas Co. Pyrite and chalcopyrite masses.

1. Silver Summit. Shoshone Co. Sec, 23, T. 48 N., R. 3 E $47^{\circ} 30^{\prime}$ $116^{\circ} 02^{\prime}$ Gersdorffite present in tetrahedrite-siderite veins. As much as $1.0 \%$ N., $0.40 \%$ Co present. Fryklund and Hutchinson, 1954.

2. Franklin. Shoshone Co. Sec. 27, T. 46 N., R. E. $47^{\circ} 18^{\prime}$ $115^{\circ} 56^{\prime}$ Gersdorffite present in chalcopyrite-siderite velns. Wagner, 1949.

3. Blackbird district. Lemh1 Co. Secs. $22,23,26,27$, T. 20 N., R. 18 E. Chalcopyrite, cobaltite and safflorite in veins in schistose Belt rocks. Includes following properties (from north to south):
A) Bonanza Copper, B) Tinker's Pride, C) Sweet Repose,
D) Long Dike, E) Calera, F) Northfield,
G) Haynes Stellite, and H) Black Pine. Vhay, 1948;
Schockey, 1957; Umpleby, 1913.

4. East Fork. Lemhi County. Cobalt minerals with 
MAINE

1. Crawford Pond. Knox Co. Pyrrhotite, chalcopyrite and

$44^{\circ} 11^{\prime}$

$69^{\circ} 15^{\prime}$ pentlandite segregated in ultramafic intrusion. $\mathrm{Ni}$, $0.6 \%$; Cu, 028\%; Co, 0.096\%. Bastin, 1908; Cornwall, 1966.

2. Katahdin Iron Works. Piscataquis Co. Pyrrhotite in $45^{\circ} 33^{\prime}$ $69^{\circ} 10^{\prime}$ gabbro. Young, 1968.

3. Black Narrows, Moxie Lake. Somerset Co. $\mathrm{Cu}-\mathrm{Ni}-\mathrm{Co}$ in peridotite. Young, 1968.

$45^{\circ} 19^{\prime}$ $69^{\circ} 50^{\prime}$

4. Alexander area, Washington $\mathrm{Co}$. $\mathrm{Cu}-\mathrm{Ni}-\mathrm{Co}$ in ultramafic bodies. Young, 1968.

$45^{\circ} 07^{\prime}$

$67^{\circ} 28^{\prime}$

\section{MARYLAND}

1. Patapsco. Carroll Co. Carrollite with chalcopyrite and other sulfides in veins in schist. Heyl and Pearre, 1965.

2. Mineral Hill. Carroll Co. Magnetite, carrollite, chalcopyrite, sphalerite in chlorite gange in metagabbro. Heyl and Pearre, 1965.

3. Carroll, probably similar to Patapsco and Mineral Hill deposits. Carroll Co. Heyl and Pearre, 1965.

4. Bare Hills, Baltimore Co. Chalcopyrite, bornite, and magnetite (probably carrollite also) in vein in hornblende schist.

\section{MINNESOTA}

1. Kawishiwi River area. Lake Co. Sec. 5, T.61 N., R. $11 \mathrm{~W}$; secs. $25,26,32,33,34, \mathrm{~T} .62 \mathrm{~N}$. , R. $11 \mathrm{~W}$. Disseminated pyrrhotite, chalcopyrite, cubanite, and pentlandite along contact of Duluth gabbro. Cu 0.49\%, Ni 0.14\%. Grosh, 1955; Schwartz and Davidson, 1952.

\section{MISSOURI}

1. Fredericktown. Madison Co. Sec. 16, T. 33 N., R. 7 E.

Snyder and Odell, 1958. 
MONTANA

1. Cherry Creek. Madison Co. Sec. 28, T. 8 S., R. 1 W.

$45^{\circ} 07^{\prime}$

$111^{\circ} 4^{\prime}$

Manganese oxide deposits. Hollandite carries $2.29 \%$

Co. Hewett and Fleischer, 1960.

2. Mouat Nickel. Stillwater Co. Secs. 20, 29, T. 5 S.,

$45^{\circ} 21^{\prime}$

$109^{\circ} 51^{\prime}$

R. 15 E. Pyrrhotite, chalcopyrite and pentlandite

disseminated and in masses of base of Stillwater Complex, $\mathrm{Ni}, 0.4 \% ; \mathrm{Cu}, 0.35 \%$; Co, $0.025 \%$. Cornwa11, 1966 .

\section{NEVADA}

1. Lovelock (Table Mountain). Churchill Co. Sec. 34,

$40^{\circ} 00^{\prime}$

$117^{\circ} 55^{\prime}$

T. $25 \mathrm{~N} .$, R. $36 \mathrm{E}$. Nickel and cobalt minerals in

copper deposit in altered greenstone near diorite

intrusion. Ferguson, 1939.

2. Gibellini. Eureka Co. Sec. 11, T. 16 N., R. 52 E.

Psilomelane and pyrolusite carrying $\mathrm{Zn}, \mathrm{Ni}$, Co,

and $\mathrm{Cu}$. Binyon, 1948.

3. Copper Chief (Goodsprings). Clark Co. Sec. 35,

T. 24 S., R. 57 E. Heterogenite in and around

oxidized copper deposits in dolomite. Hewett, 1931.

4. Great Eastern and Key West. Clark Co. Hydrothermally

$36^{\circ} 40^{\prime}$

$114^{\circ} 10^{\prime}$

altered magmatic differentiates of pyrrhotite,

chalcopyrite and pentlandite in ultramafic dikes.

One carload $\mathrm{Cu}, 2.30 \%$; Ni. $1.79 \%$; Co. $0.08 \%$;

Pt, $0.13 \mathrm{oz} /$ ton. Needham and others, 1950.

\section{NEW MEXICO}

1. Blackhawk. Grant Co. Sec. 21, T. 18 S., R. 16 W.

Native silver, argentite, nickel-skutterudite, pitchblende, and less sphalerite, chalcopyrite and galena in vein in gneiss. One sample showed $\mathrm{Ni}, 8.9 \%$; Co, 0.9\%. Gillerman and Whitebread, 1956.

2. Manganese Valley, Luna, Killion. Luna Co. T. 24 S., R. $7 \mathrm{~W}$. Manganese oxide deposit carrying some cobalt. $32^{\circ} 15^{\prime}$ $107^{\circ} 35^{\prime}$ Lasky, 1940; Hewett and Fleischer, 1960. 


\section{NORTH CAROLINA}

1. Ore Knob. Ashe Co. Pyrrhotite, pyrite and chalcopyrite $36^{\circ} 24^{\prime}$ $81^{\circ} 22^{\prime}$ disseminated and massive in shear zone in Carolina gneiss. Cu:Co $=45.1$. Egleston, 1881 .

\section{OREGON}

1. Standard (Quartzburg). Grant Co. Sec. 12, T. 12 S., $44^{\circ} 33^{\prime}$ $118^{\circ} 41^{\prime}$ R. 33 E. Glaucodot, safflorite, cabaltite, chalcopyrite and gold in vein cutting metavolcanic rocks. Vhay, 1959.

2. Nickel Mountain (Riddle). Douglas Co. Sec. 17, T. 30 S., $42^{\circ} 58^{\prime}$ $123^{\circ} 26^{\prime}$ R. $6 \mathrm{~W}$. Garnierite in laterite overlying peridotite. Pecora and Hobbs, 1941. Bogert, 1960; Hotz, 1964.

3. Red Flats area. Curry Co. Secs. 19, 30, T. 37 S., $42^{\circ} 21^{\prime}$ $124^{\circ} 18^{\prime}$ R. $13 \mathrm{~W}$. Nickeliferous laterite overlying serpentine. $\mathrm{Ni}, 0.9 \%$; Co, 0.3\%. Dole, 1948; Hundhausen, 1954.

4. Shamrock. Jackson Co. Secs. 19, 20, T. 14 S., $42^{\circ} 36^{\prime}$ $122^{\circ} 59^{\prime}$ R. $2 \mathrm{~W}$. Pyrrhotite, pentlandite and chalcopyrite disseminated and in masses in ultramafic sills in greenstone. $\mathrm{Cu}, 1.1 \%$; $\mathrm{Ni}, 1.3 \%$; Co, $0.07 \%$. Hundhausen, 1952. Shelton, 1956.

5. Cowboy (Takilma-Waldo). Josephine Co. Sec. 11, T. 41 S., R. 8 W. Pyrrhotite, cobaltite, chalcopyrite, $42^{\circ} 01^{\prime}$ cubanite and sphalerite in irregular masses in fault in serpentine near contact with greenstone. Ore boulder assayed $18.7 \% \mathrm{Cu}, 0.24 \% \mathrm{Zn}, 0.24 \% \mathrm{Co}, 0.11 \%$ Ni. Shenon, 1933.

\section{PENNSYLVANIA}

1. Gap Nickel mine. Lancaster Co. Pyrrhotite, chalcopyrite and pentlandite along contact of gabbro with mica schist. $2.3 \% \mathrm{Ni}, 0.1 \%$ Co. Phemister, 1924; Knopf and Jonas, 1929.

2. Grace. Berks Co. Magnetite ore in skarn deposits. Sims, 1968.

3. Cornwa11. Lebanon Co. Magnetite ore in skarn deposits. $39^{\circ} 57^{\prime}$ $76^{\circ} 05^{\prime}$ Vnay, 1952. 


\title{
TENNESSEE
}

1. Scott prospect. Johnson Co. Manganese oxide deposit.

$36^{\circ} 31^{\prime}$

$81^{\circ} 57^{\prime}$

Hollandite and pyrolusite in residual clay on Shady

dolomite. King. 1944.

2. Hodge ore banks (Stony Creek). Carter Co. Old iron mines. Manganese oxide in residual clay on Shady dolomite. King, 1944, Harder, 1910.

3. Blue Spring. Carter Co. Manganese oxide in residual clay on Shady dolomite near contact with Erwin quartzite. King, 1944.

4. Proffit prospect. Johnson Co. Hard manganese oxide cements broken quartzite and jasperoid on fault(?) contact between Erwin formation and Shady dolomite. Psilomeland carries $0.3 \%$ Co.

5. Bumpass Cove. Unicoi and Washington Cos. Manganese oxide nodules in residual clay on Shady dolomite; $0.09 \%$ to $0.14 \%$ Co reported. King, 1944; Pierce, 1944; Stose and Schrader, 1923.

6. Nunnelly. Hickman Co. Hard manganese oxide in seams in $35^{\circ} 4^{\prime}$ $87^{\circ} 40^{\prime}$ Fort Payne chert. One sample showed $52.9 \% \mathrm{MnO}_{2} ; 1.16 \%$ $\mathrm{Ni}$; 0.64\% Co. Burchard and others, 1934; Pierce, 1944.

7. White Oak Mountain. Bradley Co. Manganese oxides fill cracks and replace Fort Payne chert. Manganese (plus cobalt) oxides further concentrated near surface by weathering. Pierce, 1944, Stose and Schrader, 1923.

\section{VERMONT}

1. Elizabethtown. Orange Co. Pyrrhotite and chalcopyrite in masses and disseminated in schist. Calcined pyrrhotite carries $0.11 \%$ Co. Kinkel and Peterson, 1962.

\section{VIRGINIA}

1. Mineral Ridge. Cedar Creek Valley. Frederick Co. Manganese oxide nodules in residual clay overlying lower Paleozoic rocks. Stose and Miser, 1922; Monroe, 1942.

2. Cedar Creek Valley. Shenandoah Co. Manganese oxide
residual clay.

\begin{abstract}
Stose and Miser, 1922, Monroe, 1942.
\end{abstract}


3. Stanley (Eureka). Page Co. Hard manganese oxide $38^{\circ} 34^{\prime}$ 78031 nodules in residual clay overlying Tomstown (Le) dolomite. Stose and others, 1919; King, 1950.

4. Elkton mines. Rockingham Co. Manganese and iron oxides in residual clay derived from Tomstown dolomite and Waynesboro formation, and overlain by considerable gravel. Stose and others, 1919; King, 1950.

5. Crimora. Augusta Co. Manganese oxide nodules in residual clay overlying Lower Cambrian rocks. Up to $0.53 \%$ Co reported. Stose and others, 1919; Pierce, 1944.

6. Lyndhurst-Vesuvius. Augusta and Rockbridge Cos. Manganese oxide nodules in residual clay overlying Tomstown dolomite. Up to $0.95 \%$ Co reported. Stose and others, 1919; Knechtel, 1943.

7. Paint Bank. Craig Co. Manganese oxide nodules in residual clay overlying Ordovician, Silurian and Devonian rocks. Ladd and Stead, 1944.

8. Stange, Arms, Diamal Creek. Bland Co. Manganese oxide $37^{\circ} 11^{\prime}$ $80^{\circ} 54^{\prime}$ nodules in weathered Silurian and Devonian rocks. Up to $0.53 \%$ Co reported. Stose and Miser, 1922; Pierce, 1944; Ladd and Stead, 1944.

9. Suitor, Round Mountain. Bland Co. Manganese oxide nodules in weathered Devonian sandstone and in residual clay overlying Silurian 1imestone. Up to $2.24 \%$ Co reported. Stose and Miser, 1922; Pierce, 1944; Ladd and Stead, 1944.

10. Virginia Nickel Corporation. Floyd Co. Lenses of pyrrhotite-chalcopyrite pentlandite in a compound gabbro-pyroxenite dike. Watson, 1908; Ross, 1935.

11. Prospects. Smyth Co. Manganese oxide nodules in residual clay overlying Shady dolomite. Stose and others, 1919; Miller, 1944.

12. Lick Mountain. Wythe Co. Manganese oxide nodules in weathered lower Paleozoic rocks. Stose and others, $37^{\circ} 05^{\prime}$ $80^{\circ} 13^{\prime}$ 1919; Stead and Stose, 1943.

$36^{\circ} 45^{\prime}-$ $36^{\circ} 52^{\prime}$ $81^{\circ} 33^{\prime}-$ $81^{\circ} 15^{\prime}$

$36^{\circ} 55^{\prime}$ $80^{\circ} 55^{\prime}$ 
13. Gossan Lead. Carro11, Floyd, and Grayson Cos. Many large lenses of pyrrhotite, chalcopyrite and sphalerite in Carolina gneiss. Secondary copper sulfide ores. Watson, 1908; Ross, 1935; Kinkel and Peterson, 1962.

14. Toncray. Floyd Co. Pyrrhotite, chalcopyrite and pyrite masses in altered amphibolite dike cutting Carolina gneiss. Secondary chalcocite ore bodies. $\mathrm{Cu}: \mathrm{Co}=20: 1$. Watson, 1908; Ross, 1935 .

\section{WASHINGTON}

1. Mt. Vernon. Skagit Co. Secs. 4, 9, 10, T. 33 N., $48^{\circ} 20^{\prime}$ $122^{\circ} 15^{\prime}$ R. 4 E. Bravoite and other nickeliferous minerals with a little gold in brecciated silica-carbonate rock along fault between serpentine and preteritary rocks. Hobbs and Pecora, 1941.

2. Jumbo Mountain. Snohomish Co. Sec. 2, T. 31 N., R. 9 E. Pyrrhotite, pentlandite and chalcopyrite disseminated in dunite and in masses in shear zones along dunite-quartzite contact. Mills, 1960 .

3. Mackinaw. Snohomish Co. Sec. 19, T. 29 N., R. 11 E. $47^{\circ} 59^{\prime}$ $121^{\circ} 36^{\prime}$ Lenses containing niccolite, maucherite, pentlandite, chalcopyrite, cubanite, vallerite and gold in ultramafic rock near fault with Eocene arkose. Cole, 1944; Milton and Milton, 1958.

4. Anderson prospect. Stevens Co. Sec. 3, T. 39 N., $48^{\circ} 55^{\prime}$ $117^{\circ} 38^{\prime}$ R. 41 E. Galena-sphalerite ore body containing $\mathrm{Ni}$ and Co. Vhay, 1966.

5. Congress (San Poil). Ferry Co. Sec. 35, T. 32 N., $48^{\circ} 14^{\prime}$ $118^{\circ} 38^{\prime}$ R. 33 E. Pockets of Ni-pyrite and chalcopyrite in quartz vein at contact of serpentine and schist. One sample gave $0.02 \% \mathrm{Cu}, 1.2 \% \mathrm{Ni}, 0.02 \% \mathrm{Co}$.

Bancroft, 1914.

6. Shamrock (Iron Creek). Ferry Co. Sec. 35, T. 31 N., $48^{\circ} 09^{\prime}$ $118^{\circ} 38^{\prime}$ R. 33 E. Nickel and cobalt in brecciated zone in limestone near granite. Samples averaged $0.16 \% \mathrm{Ni}$ and $0.06 \%$ Co across 90 feet. Patty, 1921 . 


\section{DASHINGTON--Continued}

7. Chelan (Dick, Winesap), Entlat. Chelan Co. Sec. 9, T. 26 N., R. 21 E. Disseminated pyrrhotite, pentlandite, chalcopyrite and pyrite in faulted coarse ultramafic rock. Huntting, 1943, Patty and Relly, 1946.

\section{WEST VIRGINIA}

1. Traynham prospect. Sweet Springs. Monroe Co. Manganese oxides in residual clay developed on weathered Ordovician and Silurian rocks. Ladd, 1944. 